\title{
斜航するプロペラの整流効果に関する 実験結果について
}

\begin{abstract}
正員 湯 室 彰 規*
Some Experiments on Flow-Straightening Effect of a Propeller in Oblique Flows

by Akinori Yumuro, Member
\end{abstract}

\begin{abstract}
Summary
By utilizing propeller-rudder system with the absence of the ship body, the author conducted experiments concerning characteristics of a rudder behind the propeller in oblique flows in order to make clear flow-straightening effect of the propeller itself. The tests were performed by varying drift angle of the propeller axis, rudder angle and propeller loading systematically. Through these tests, propeller flow direction at the rudder position was obtained from the rudder direction in which normal force did not act on the rudder. The results were represented in the form of a coefficient of flow-straightening effect.

Principal conclusions obtained through the studies are as follows:

1) It was confirmed from experiments that the coefficient of flow-straightening effect is constant regardless of drift angle.

2) The coefficient estimated from direction of the resultant velocity from drifting velocity of a propeller and increased axial velocity of the slipstream agrees with the actually measured value fairly well.

3) Influence of propeller loading on the effect is remarkable. This fact is related with the problem of model-ship correlation for maneuverability.

4) This paper suggests an idea which may be called flow-straightening effect identity as a method to obtain the effect of a ship's hull using that of the propeller itself.
\end{abstract}

\section{1 緒言}

船の操縦運動を計算によって予測しようとする場合 に, 舵への流入角は流入速さとともに舵の性能を推定す る上で基本的に重要な要素となる。操縦運動する船の舵 位置に拈ける流れの方向は，船体やプロペラによる整流 効果が存在するために一般には船体に入るそれとは暴 なったものになる1),2)。著者は，さきにいくつかの船型 について整流効果の実験結果を報告したが33,4),5), その 結果には船体とプロペラの雨方の整流作用の影響が含ま れているので，それぞれの影響を分析的に調べこの作用 のメカニズムを明確にするためには，プロペラ自身によ る整流效果の性質を知ることが必要となる。船体部を切 り離したプロペラ, 舵系によるプロペラ後流中の舵特性 の研究は、これまで岡田の研究の,7)をはじめ数多くなさ れているが，その多くは直進状態を取り扱ったものであ り，プロペラが斜航状態にある場合のそれは必ずしも多 くはみられないようである。

\footnotetext{
* 石川島播磨重工業(株)技術研究所
}

本報告では，プロペラ，舵系を斜航させたときの舵特 性およびこれから得られたプロペラの整流効果について の実験結果を示している。さらにこの結果に付随した問 題として,プロペラの整流效果の実用的な推定法, この 効果に及ぼすプロペラ荷重度の影㗽，プロペラ自体の整 流特性を用いて整流効果を船体とプロペラのそれぞれに よるものに分離する考方などについて検討, 考察を行 なっている。なお，ここには例として一つの船型につい ての結果を述べているが，船型が異なった場合の結果お よび船型間の比較については稿を改めて報告する予定で ある。

\section{2 プロペラ背後の流向の定義と計測法}

著者は，さきに舵性能を対象とした奏用的な観点から， 舵に直圧力が作用しない舵の问きを舵位置における一種 の平均的な流向と見なし，これを拘束模型船を用いて求 め, 試験結果を整流係数の形で表わした3)。また方法が 簡単でかつ直接的であることから，風向板式の vane に よる試駼も併せて実施しだ)。さきの試験は船体のある 
場合のものであったが，ここで述べる船体のない場合の 試験もこの二つの方法で行なった。

前者の方法については, プロペラと舵との干渉の影響 が存在するためにこのように定められた流向は厳密には 舵のない場合汇相当するそれとは異なるであるうし，使 用する舵（厚さあるいは大きさ）によってる異なる結果 が得られる性貿のものであるが，干啮の影響が含まれて いるといら点ではより実際的である。後者の方法につい ては,プロペラ後流のような回転を伴った流れに対し てこのような方法を用いることの適否の問題があり, vane の示方方问の意味についても詳しい検討がなされ なければならないが，方法が極めて簡単である上に舵の 厚みによる干渉の影显が除外された結果が得られるとい う特徵がある。後者の方法では使用する vane の種類に よって買なった結果が得られると考光られるので, vane の大きさ，配置埸所を変えた場合の实験を行なってい る。

\section{3 供試模型および試験装置}

\section{1 供試模型と試験状態}

この報告にはタンカー船型のプロペラ, 航についての 試験結果を示した。尺度影響の観点からはできるだけ寸 法の大きいものを候用することが望ましいが，さきに得 られている船体のある場合の結果をさらに分析的に検討 するのがこの实験の主要な目的であることもあり，便宜 上その模型船に装備されているものをそのまま使用し た。さらにプロペラと舵との相対位置, 没水深度につい ても船体に取り付けられている状態に同じとした。プロ ペラ, 舵怙よびこれらが装借されている船体の要目を Table 1 に示す。プロペラ軸の没水深度は $1.6 D$, プロ ペラボス中心と舵前縁との間隔は $0.28 D(D:$ プロペラ
Table 1 Particulars of model

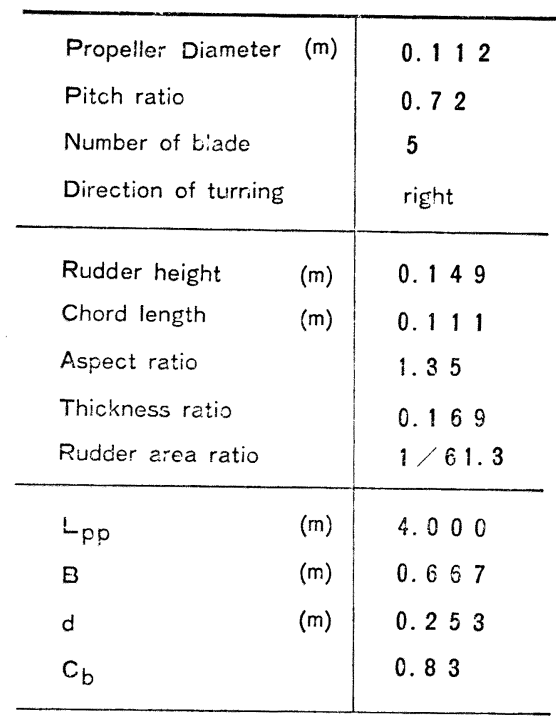

直径) である。前進常数については, Table 1 の模型船 よりもさらに小さい長さ $2.25 \mathrm{~m}$ の模型船打よび実船(長 さ $300 \mathrm{~m})$ の自航状態 $\left.{ }^{8}\right)$ に対応する值を含む領域内にお いて幾種類かに变化させた。

\section{2 プロペラ駆動装置}

使用したプロペラ駆動装置は駆動用の排水体を前方に して走行させる形式のもので，その概略図を Fig. 1 亿示 している。図中，下段に正面戝を，上段に平面図を示し ている。この形式を採用するとき問題となるのは, プ ロペラや舵の性能が排水体や支柱の後流の影響を受けて 好ましくないことであるが，装置の製作に当っては没水 体部の容積を極力小さくするとともに，プロペラ軸に斜 航角をつけても支柱は常に流れと平行状態に保たれる 機構を採って拈り,これらによるかく乱ができるだけ小

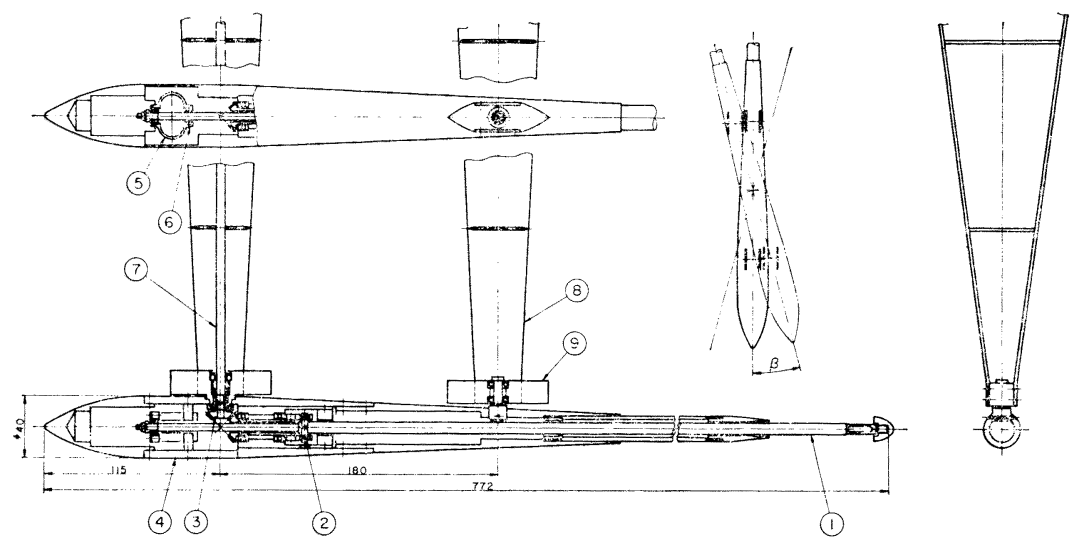

Fig. 1 Apparatus for propeller driving; (1) Propeller shaft (2) Thrust free coupling (3) Bevel gear (4) Sword (5) Thrust sensor (6) Fixed:part in thrust sensor (7) Driving shaft (8) Strut (9) Fin equipped with strut 
さくなるように十分な配慮がなされている。排水体の前 端部にスラスト検出部が内藏されており, 極めて小型の 駆動装置ではあるがスラストの計測が可能なようになっ ている。

\section{4 プロペラ整流効果の実験結果と考察}

\section{1 プロペラ駆動装置の伴流計測}

没水体部が後方の流場に及ぼす影響について確認して おくために, プロペラ駆動装置を斜航させた埸合の伴流 計測を行なった。その結果をFig. 2 亿示す。ここでxは 一㥞流の方向のプロペラ朝端からの距嵟とし，yはこれ と直角方向で斜航状態の内側を正とする。縱断面に括け る計測は，プロペラ軸端位置を中心として左右，上下に $25 \mathrm{~mm}$ 間隔で $\pm 50 \mathrm{~mm}$ の簕圆で奏施したが，プロペラ 軸以外の深さの位置における影響は注とんぞ無視できる

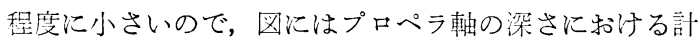
測結果のみを示している。プロペラ軸先端部の背後で は，流速減少率，流れの偏向角は多少大きな值を示すが ごく局所的であり，後述するように舵のような広い面に わたる平均値が対象となるような場合には，この影響は 実用的には無視できる。

\section{2 舵力特性から求的た整流係数}

斜航角 $\beta$ および舵角 $\delta$ を系統的に変化さ怘たときのプ ロペラ後流中の舵直圧力の計測結果の例を Fig. 3 亿示 す。これらの符号は Fig. 4のように定める。直生力係数 $C_{. V}$ 扩よび前進常数 $J$ の定義にはプロペラの前進方向 の速度 $V$ を用いている。図中 $J=0.380$ は実船状態汇, $J=0.253$ は模型船（長さ $4 \mathrm{~m}$ ) 状態に大略対応してい る。
$C_{N}$ 曲線が横軸と交わる点，すなわり舵に直圧力が作 用しない舵の向きを求め, この結果をFig. 5 の定義偟 る整流係数の形で示したのが Fig. 6(a) である。この結 果をプロペラ整流保数と称することにし， $C_{p}$ の記号を用 いることにする。この四より $C_{p}$ の值は $\beta$ に対して一定 と見なすことができる。この性質は運動量理論からも簡

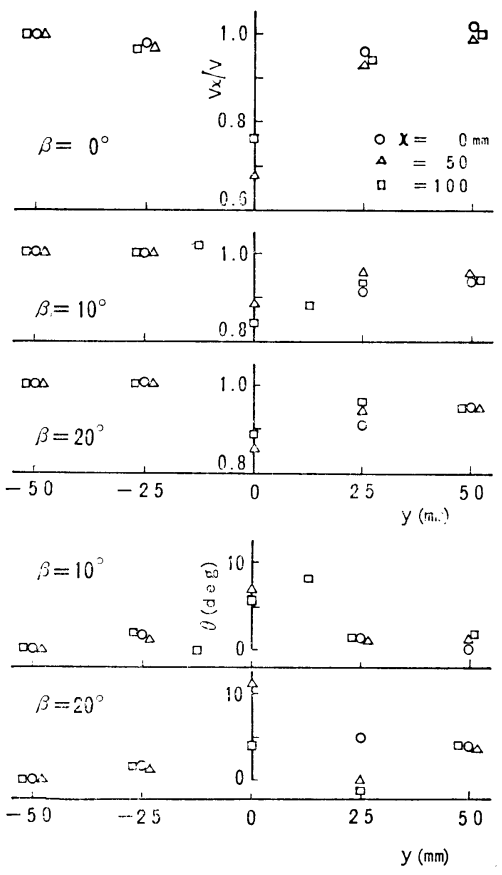

Fig. 2 Wake measurement of propeller driving apparatus (in depth of propeller shaft)

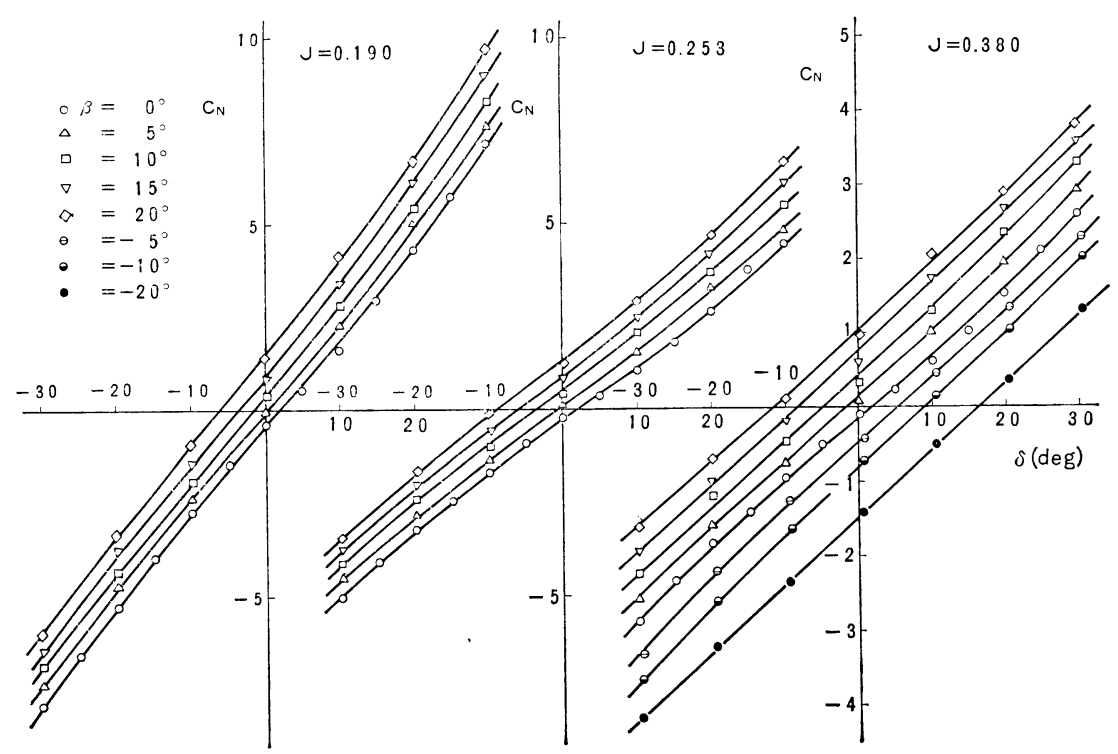

Fig. 3 Example of measured results of rudder normal force 
単に導かれるものであるが，ここで奏駼的にも確められ たことになる。

以上のような舵特性に明する实䟻において，プロペラ

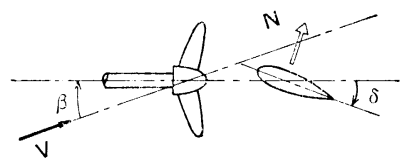

Fig. 4 Sign definition

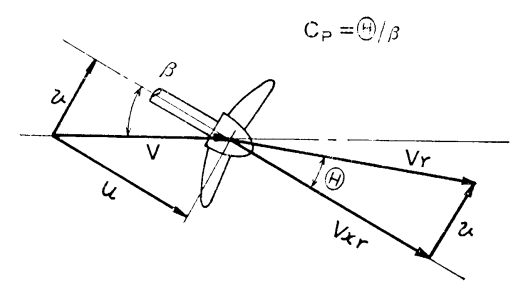

Fig. 5 Notation and definition of flowstraightening effect coefficient

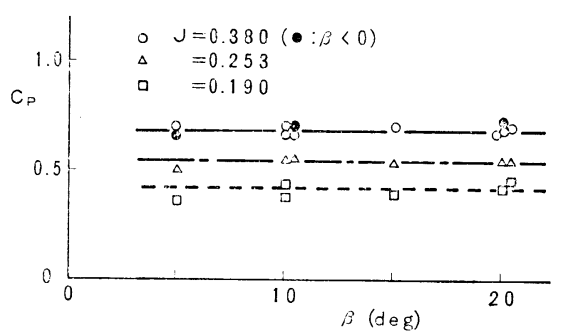

Fig. 6(a) Example of measured results of flow-straightening eifect coefficient obtained from rudder force

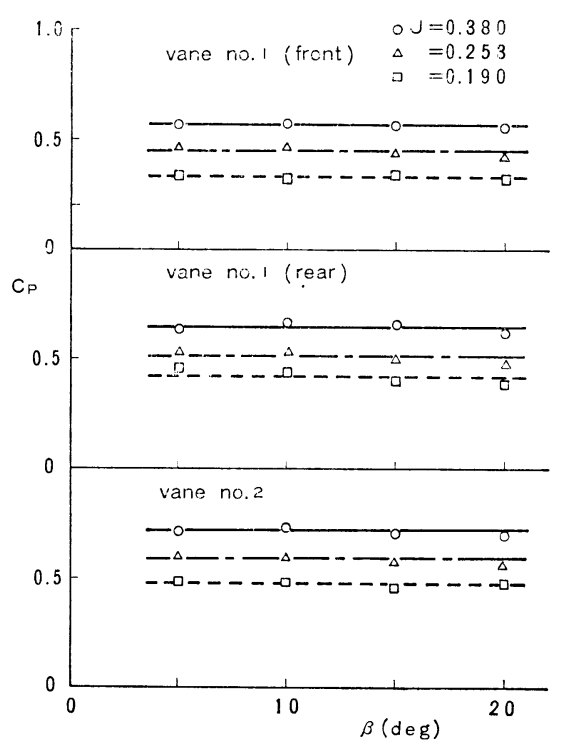

Fig. 6(b) Example of measured results of flow-straightening effect coefficient obtained using vanes
駆勳装置の没水体部がどの程度の影響を与えるかを確認 するために，プロペラを取りはずした状態で舵力の計測 を行なった。直压力の結果をFig. 7(a) に示す。この結 果から流向に対する影響は無視できること, 流速に対す る影響については単独舵の結果との比較から， $\beta=0^{\circ}$ で $3 \%$ 程度, $10^{\circ}$ 以上の状態では大体 $1 \%$ 以下の減少とな る。流入速度のこの程度の減少の影蠁は, プロペラ後流 中の舵特性の間題を考える場合には実用的には汪とんど 無視できる。

\section{3 vane の方法 ${ }^{3)} よ り$ 求めた整流係数}

使用した羽根の種類を Table 2 に示す。羽根 No. 2 は高さ，蝠がそれぞれプロペラ值径，舵弦長に注ぼ等し いもので, 羽根 No. 1 は No. 2 の幅の寸法を $1 / 2$ 亿し たものである。

舵弦にわたる平均的な流向をみるために羽根 No. 2 を舵位置に置いた場合，およでこの籍囲における変化の ごく大まかな傾向をみるために羽根 No. 1 を舵面の前

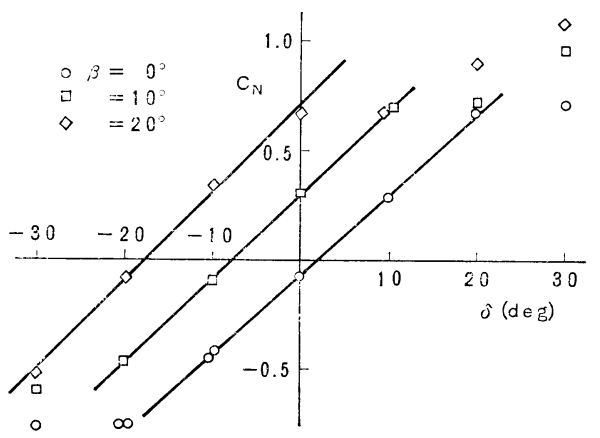

Fig. 7(a) Disturbance given to uniform flow due to submerged body of propeller driving apparatus (detected by rudder)
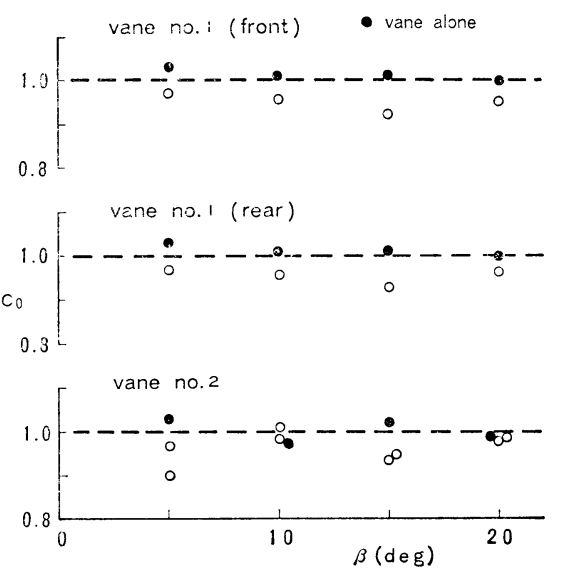

Fig. 7 (b) Disturbance given to uniform flow due to submerged body of propeller driving apparatus (detected by vane) 
Table 2 Dimensions of vanes used in measuring flow direction

\begin{tabular}{|c|c|c|c|}
\hline & span & chord & thickness \\
\hline Vane no. I & 100 & 60 & 2 \\
\hline Vane no.2 & 100 & 100 & 2 \\
\hline
\end{tabular}

Unit : $\mathrm{mm}$

半部あるいは後半部に置いた場合の計測を行なった。そ れらの結果の例を Fig. 6 (b) に示す。羽根 No.1を舵 の後方部酒配置したときの $C_{p}$ の值は前方部に配置した ときのそれよりる大きくなっているが，これはプロペラ 後流の一様流からの偏り角がプロペラから遠ざかるにつ れて小さくなることを示して扬り，一応もっともらしい 結果を与えている。羽根 No. 2 による $C_{p}$ はさきの 2 者よりも大きい值を与兄ている。プロペラ後流を理想化 された噴流管と見なせば羽根は一種の曲り流れの中に置 かれていることになるが，この場合羽根の幅の大きさと $C_{p}$ の值には関連があり幅の增大は $C_{p}$ の值を大きくす る性質がある (4.4 で後述)。一つの推論としてこのこと も上述の結果に対する理由の一つと考兄ることができる が，な扮検討が必要である。

羽根の方法による場合についても流向に及添すプロペ ラ駆動装置の没水体部の影響の確認を行なったので, そ の結果（整流係数で表わして $C_{0}$ とする）を Fig.7(b) に示す。この場合も影響は微小であることが知られる。

\section{4 両方法による結果の比較}

それぞれの力法で得られた Fig. 6(a)，（b)の $C_{p}$ の 值を比較すると, 舵特性の方法から得られた㯰は羽根 No. 1 を舵の後半部に置いたときの値に最も近く, 両者 はほぼ一致していることがわかる。前進常数のさらに広 い範围にわたって雨結果を比較したのが Fig. 8 である。 羽根 No. 1 をこの位置に置いたとき羽根の中心は舵の $3 / 4$ 弦長点汇対応して拈り, この羽根の向く方向隹舵を 置けば直圧力が作用しないといら結果になっている。こ の事実は翼理論に括けるいわゆる $3 / 4$ 弦長点の定理9に 相当していると考光ることができる。舵特性に対しては

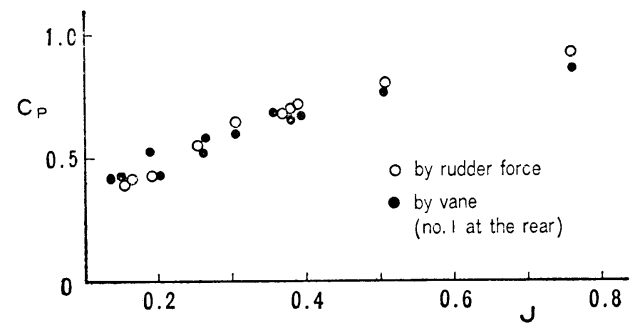

Fig. 8 Comparison of flow-straightening effect coefficients determined from rudder force and vane direction
その前半部よりも後半部に怙ける流向がより支配的であ ることがこのような簡単な実験によっても示されたこと になる。

$3 / 4$ 弦長点の定理はもともと 2 次元平面翼が一様流中 にある場合について導かれたものであるが，この結果は 流れが一様でなく曲り流れになっている場合にも成立す ることが次のように示される。翼弦長中点に原点を置 き，弦方向に $x$ 軸，これに垂百に $y$ 軸をとる。いま翼の 迎角を $\alpha$ と，流れの $y$ 方向の成分が $V \sin \alpha+v_{1} x て ゙$ 与えられるような流場を考学る10)。渦なし流れの場合は その条件からこれに応ずる $x$ 方向の成分は $V \cos \alpha+v_{1} y$ となるが， $v_{1}$ が十分に小さいかあるいはyの小さい領

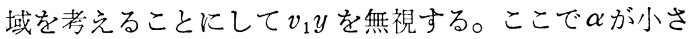
いとし，便宜上 $V$ を $x$ 軸方向にとり翼に迎角がとられて いる状態を考觉る。このように仮定すると流れとしては $y$ 方向, $x$ 方向の流速がそれぞれ

$$
\frac{d y}{d t}=v_{1} x, \quad \frac{d x}{d t}=V
$$

となるからここょり

$$
y=\frac{v_{1}}{2 V} x^{2}
$$

となる。このような流れの中に置かれた 2 次元平面翼の 循環は

$$
\Gamma=-\frac{\pi c V}{2}\left(2 \alpha+\frac{v_{1} c}{2 V}\right)
$$

となり，掦力保数は

$$
C_{l}=\pi\left(2 \alpha+\frac{v_{1} c}{2 V}\right)
$$

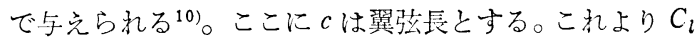
が 0 となる迎角は

$$
\alpha=-\frac{v_{1} c}{4 V}
$$

となる。一方，流れの $3 / 4$ 弦長点の位管における勾配は

$$
\left(\frac{d y}{d x}\right)_{x=c / 4}=\frac{v_{1} c}{4 V}
$$

となって揚力の作用しない迎伊に一致する。なお，（3） 式は $C_{l}$ が 0 となる迎角は弦長比比例して增加すること を示して抢り，前節の幅の大きい羽根の $C_{p}$ が他の場合 のそれよりも大きい值を示すといら結果とも関速してい ると推察される。

雨方法には厳密には舵の厚さの影響，プロペラ百径と 舵高さの差異の影響など条件に多少の違いはあるが，こ のように一応の関連づけはできる。このような簡単な方 法によっても舵特性の方法による結果と大略同程度のも のが得られるということは実用的な意味に执いては非常 飞便利である。

\section{5 プロペラ整流効果に及ぼす荷重度の影響}

プロペラ整流係数を前進常数を横軸にして表示した結 


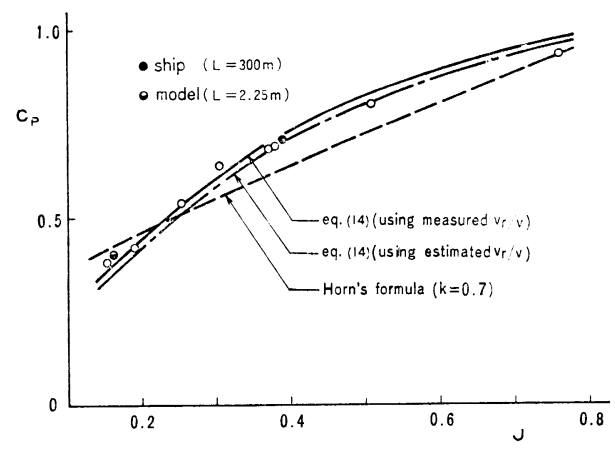

Fig. 9 Effect of propeller loading on flow-straightening effect

Table 3 Scale effect on coefficient of flow-straightening effect

\begin{tabular}{l|c|c|c}
\hline \multirow{2}{*}{$\begin{array}{c}\text { Method of } \\
\text { measurement }\end{array}$} & $\begin{array}{c}\text { Coefficient } \\
\text { Model } \\
(\mathrm{J}=0.162)\end{array}$ & $\begin{array}{c}(2) \\
\text { Ship } \\
(\mathrm{J}=0.38\end{array}$ & $(1) /(2)$ \\
\hline Rudder force & 0.400 & 0.700 & 0.571 \\
\hline Vane & & & \\
No.I (front) & 0.375 & 0.620 & 0.605 \\
No.I (rear) & 0.400 & 0.665 & 0.602 \\
No.2 & 0.420 & 0.750 & 0.560 \\
\hline
\end{tabular}

果がFig. 9 である。図には前述の実船および模型船の状 態に対する值も記入しているが，両者にはかなり大きい 差が喼められる。Table 3 に雨者の比を示す。これによ ると整流係数の計測方法によって多少の差はみられる が，この比はお执よそ0.6 前後の值となり，舵特性に及 ぼすプロペラ整流効果の縮率影響は無視し得ないほど大 きいことが知られる。

船の操縦運動によって舵に生ずる直圧力はここで定義 した整流係数に比例するので, これの推定の誤差はその まま舵直圧力の精度に関係する。この影響の仕方は操縦 運動の状態によっても買なる。例えば旋回運動を考える 場合, 操舵終了直後では小さいが旋回が発達すると大き くなる。また舵中央で船が横すべり運動をしている状態 を考えると，このとき発生する舵直圧力はこの運動に対 する滅衰力として作用するが，整流効果の縮率影響は模 型船においてこの作用を減ずる方向に働く。

\section{5 プロペラ整流係数の推定}

ここではプロペラ整流係数をプロペラスラストの関数 として取り扱う関係上, まずプロペラ, 舵系に括ける舵 特性の計測時に得られたスラストの結果について述べ, 次にこの実測値を用いて検討したプロペラ整流係数の推 定法について述べる。

\section{1 スラストの実験結果}

プロペラ単独の状態で斜航角 $\beta$ を変えたときのスラス

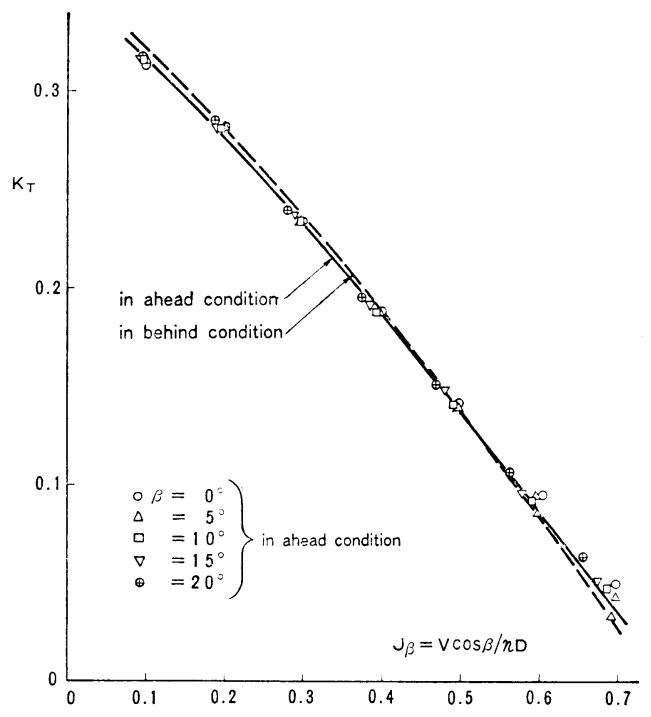

Fig. 10 Result of propeller thrust measurement (without rudder)

トの計湘結果を Fig. 10 に示す。文献 11) に倣って横軸 にはプロペラ軸方向の速度成分を用いた前進常数 $J_{\beta}=V$ $\cos \beta / n D$ をとっている。この図にはプロペラ駆動装置 の没水体部を前方および後方にして走行させた場合の結 果の比較を示しているが, 没水体部のプロペラ性能に及 ぼす影響は操縱性を対象とする限り無視しても差しつか えない程度と考えることができる。

Fig. 11 に舵がある状態で斜航角 $\beta$, 舵角 $\delta$ を变化さ せたときのスラストの計測結果の例を示す。 $\beta, \delta$ のそれ ぞれの影響をみるためにまず $\beta=0^{\circ}$ として $\delta$ を変化 させた場合の結果が Fig. 12(a) である。ここで舵の存

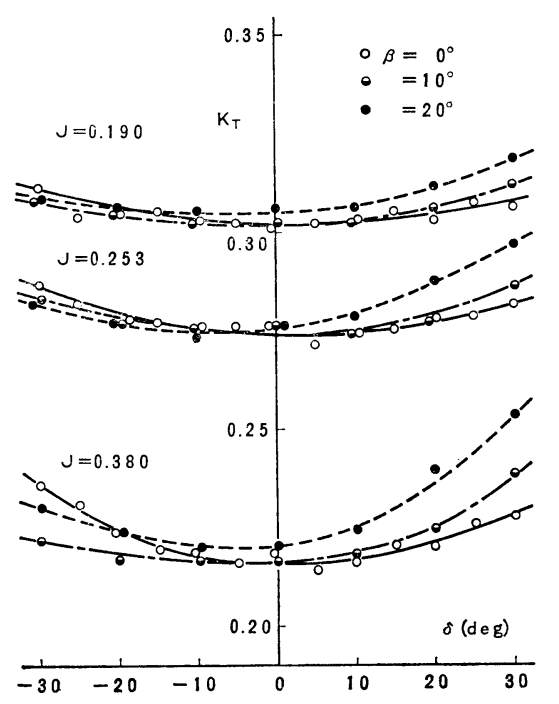

Fig. 11 Result of propeller thrust measurement (with rudder) 
在の影響も併せて表わすために舵のある場合とない場合 との比で示している。次に $\delta=0^{\circ}$ として $\beta$ を変化させた ときの結果が Fig. 12（b）であり，純粋に $\beta$ のみの影響 をみるために舵のない場合の結果を示したのが Fig. 12 (c)である。これらの結果から, 既に理論的研究 ${ }^{12), 13)}$ に よってる明らかにされていることであるが，及あるいは ○の影響よりも舵の存在による影響の方が大きいこと， Fig. 12(b) 飞执いてスラスト常数 $K_{T}$ は $\beta$ 亿対してほ ぼ一定值と見なすことができることがわかる。後者につ いては本来舵のないときは $K_{T}$ は $\beta$ に対して增加する が,一方, 舵を避けて通過する流れの割合が大きくなるの

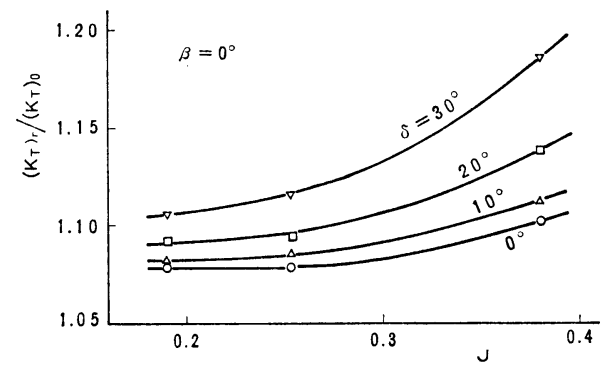

Fig. 12(a) Effect of rudder angle on propeller thrust $\left(\beta=0^{\circ}\right)$

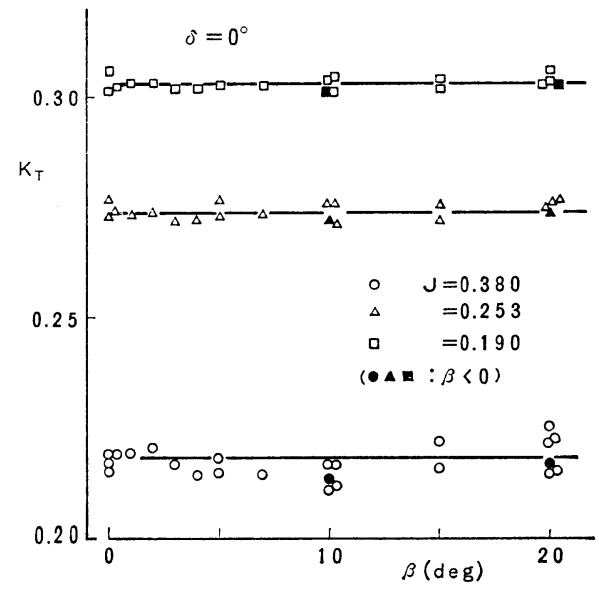

Fig. 12(b) Effect of drift angle on propeller thrust (with rudder, $\delta=0^{\circ}$ )

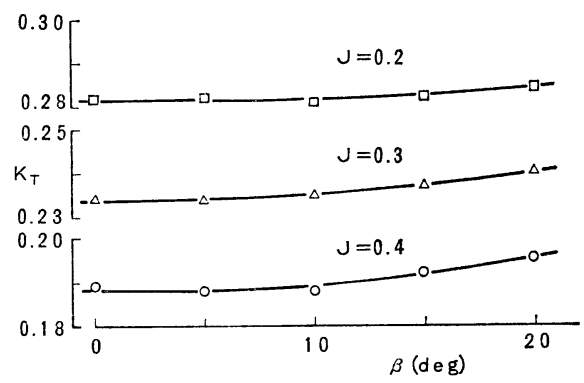

Fig. 12(c) Effect of drift angle on propeller thrust (without rudder)
で舵による影響が小さくなり，これらの効果が相殺され るためであると考えることができる。

以上の結果に見られるごとくスラストに与える舵の存 在の影響が比較的大きいので, 以後の整流俰数の推定計 算では干渉の影響を含んだ值として舵のある場合のスラ ストを用いる。また舵角が大きくないときは $\beta$ や $\delta$ の影 響は小さいとして $\beta=0^{\circ}, \delta=0^{\circ}$ の值で代表させること とする。

\subsection{Horn の算式 ${ }^{14)}$ による方法}

実用的な算定法の一つとして Horn の方法について検 討してみる。この方法によるプロペラ横力の計算値は実 験值よりる大きくなることが文献 15）で示されている が，このことは整流係数でい光ば計算値の方が小さくな ることに対応している。事実ここで得られた整流係数の 実測値と比較すると算定式によるものの方がかなり小さ い值を与えるよらである。ここでは Horn の算式に実験 的な修正係数を与学ることを考光る。そこでまず，後の 考察の便宜上あえてこの算式の誘導過程の概要を次に述 べておくことにする。記号は本稿のものに合せて Fig. 5 のものを用いる。

単位時問当りにプロペラから出る流量を $Q$, 横方向に 誘起される速度を $C_{q}$ とすると,プロペラ横力は運動量 の法則から

$$
P_{q}=\rho Q C_{q} \fallingdotseq \rho Q V(\beta-\Theta) \doteqdot \rho Q u(\beta-\Theta)
$$

で与兄られる。またプロペラを四込点で谓きか光，その 強さを $E$ とすると, この特異点は横方向に

$$
P_{q}=\rho E v \fallingdotseq \rho E V \beta \fallingdotseq \rho E u \beta
$$

の大きさの力を受ける。ここで $\beta-\Theta, \beta$ は小ざいと仮 定されている。(5)，(6)式より

$$
\Theta=\left(1-\frac{E}{Q}\right) \beta
$$

が得られる。ここで

$$
Q=\frac{F u}{2}\left(1+\sqrt{1+\zeta_{s}}\right)
$$

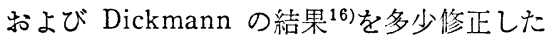

$$
E=\frac{F u}{2} \frac{\zeta_{s}}{\sqrt{1+} \overline{\zeta_{s}}}
$$

の関係式を用いると

$$
\Theta=\left[1-\frac{\zeta_{s}}{\sqrt{ } 1+\zeta_{s}\left(1+\sqrt{1+\zeta_{s}}\right)}\right] \beta
$$

が得られる。ただし， $\zeta_{S}=S / \frac{1}{2} \rho u^{2} F(S:$ スラスト， $F$ ： プロペラ円盤面積）である。以上が（10）式の誘導法の 要旨である。

以上の方法では横方向の運動量の変化は（5）式で与 えられるとしているが，プロペラ後流の速さ $V_{r}$ を用い て $\rho Q V_{r}(\beta-\Theta)$ とする方がより実際に近いと考光られ る17)。このような取扱いをする場合は（7）式に対灾す 
るあのとして

$$
\Theta=\left(1-\frac{V}{V_{r}} \frac{E}{Q}\right) \beta
$$

が得られる。( 6 )式の $P_{q}$ が実験值よりも大きい値を与 えることは，Eの值が過大に見積られていることを意味 する。そこでこれに対する補正と $V / V_{r}<1$ の効果など を一つにまとめた修正係数 $k(<1)$ を用い，(10)式を整 流倸数の形で表わすと, 結局

$$
C_{p}=1-k \frac{\zeta_{s}}{\sqrt{ } 1+\zeta_{s}\left(1+\sqrt{ } 1+\zeta_{s}\right)}
$$

となる。

整流俰数の実測結果から $k$ の值を定めると 0.7 程度と なる。いま $k=0.7$ としたときの計算值を Fig. 9 亿記入 して実測値と比較した。 $k$ の值はプロペラ荷重度によっ て変化させるべきであるが，このように一定値として取 り扱っても（12）式による算定值は前進常数による変化 の実測結果に略々追従している。Horn の算式はごく近 似的な方法で得られた結果であるのである程度の修正は 必要であるが，極めて実用的であり大略の值を知るのに 便利汇用いることができる。

\section{3 速度の合成から求める方法 ${ }^{18), 19)}$}

プロペラ軸とある角度をなして入る一様流を軸方向と それに直角方向の 2 つの成分に分け，前者のみがプロペ ラにより増速されるものとする。2 方向の流れに分ける 近似は，物体が十分薄い形状の上うな場合には成り立つ と考觉られる。このように仮定すると，Fig. 5 亿示す関 保から日は次のように表わすことができる。

$$
\Theta=\tan ^{-1} \frac{v}{V_{x r}}
$$

ここに $V_{x r}$ は舵への流入速度のプロペラ軸方向の成分 とする。 $v=V \sin \beta$ と置き, 近似的に $V_{x r}$ の代りに舵 への流入速度 $V_{r}$ を用い, $\beta$ は小さいとすると, プロペ ラ整流保数は

$$
C_{p}=\frac{\Theta}{\beta} \fallingdotseq \frac{V}{V_{r}}
$$

と表わされる。

$V_{r}$ の值として舵特性から定められた平均流入速度3) を用いる。従来多くのプロペラ後流速さの算定式が示さ れているが，ここでは例として文献 20)の式

$$
V_{r}^{\prime}=V+k \cdot \frac{1}{2}\left[\sqrt{V^{2}+10 n^{2} K_{T} \cdot R_{\vec{p}}^{2}}-V\right] \quad(k=1.0)
$$

を用い，平均流入速度は

$$
V_{r}=\sqrt{\frac{A_{1}}{A} V_{r}^{\prime 2}+\frac{A_{2}}{A} V^{2}}
$$

によるものとする。ここに, $R_{p}$ : プロペラ半径, $A$ : 舵 面積， $A_{1} ， A_{2}$ はそれぞれプロペラ後流に入っている部 分と入っていない部分の面積を示す。Fig. 13 に $V_{r}$ の計 算值と計測値との比較を示す。ただ（15）式に括注る

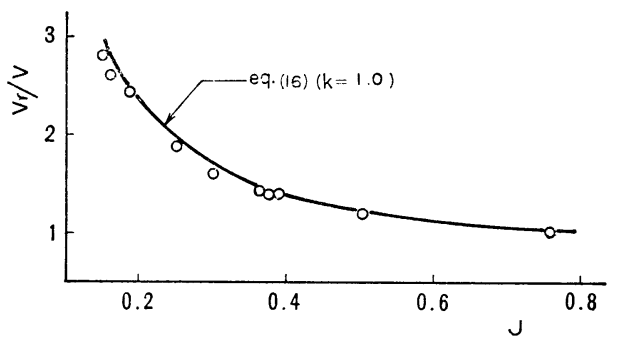

Fig. 13 Comparison between experimental and calculated inflow velocity to rudder

$k$ の值は原論文では 1.2 としているが，ここでは 1.0 と している。

（14）～(16）式による $C_{p}$ の推定値と実測値との比較を Fig. 9 に示した。推定値は Horn の方法によるものよ りも実測值に近い結果を与えており, 実測値と極めてよ い一致を示している。従って, プロペラ後流の速ささ文 正確に推定することができれば，十分な精度で整流係数 が得られることになる。また以上の結果より，文献 19） で示されている舵への流入角の算定方法の妥当性が, プ ロペラ単独の場合について検証されたことになる。

\section{6 船体による整流効果}

以上に怙いてプロペラ自体による整流効果について述 べたが，これと船体にプロペラが付いている場合の結果 から船体自身による整流効果（流向変化）を求めること を若える。この考光方はいわゆる推力一致法に対応し て，プロペラの整流作用を介してプロペラへの流入角を 求めるもので整流効果一致法とも呼ぶことができる。

船体に入る流れが船体とプロペラによって順次整流さ れる模様を Fig. 14 のように表わす。船体自身による整 流効果の保数 (船体整流係数)を $C_{s}$, 船体にプロペラが 付いた場合のそれをCで表わすことにすると, 整流俰数 の定義から

$$
\left.\begin{array}{c}
C=\frac{\Theta}{\beta}=\frac{\Theta_{p}}{\beta} \\
C_{p}=\frac{\Theta_{p}}{\Theta_{s}}, \quad C_{s}=\frac{\Theta_{s}}{\beta}
\end{array}\right\}
$$

となるので, これから

$$
C=\frac{\Theta_{p}}{\Theta_{s}} \frac{\Theta_{s}}{\beta}=C_{p} \cdot C_{s}
$$

の開係式が得られる。(18) 式の関係より $C, C_{p}$ から $C_{s}$

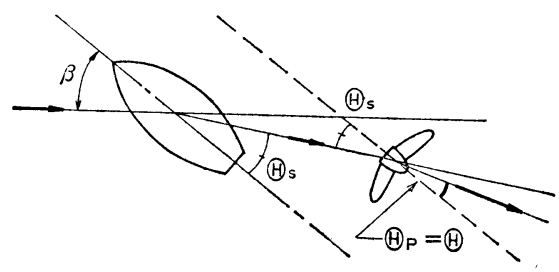

Fig. 14 Notation 
の值を求めた結果を Fig. 15 に示す。四にはプロペラ 荷重度をいくつか変えた場合の $C_{S}$ の結果を示している が，それらは荷重度に無関係にほぼ同程度の值になって おり, 一応もっともらしい結果を与えている。ここで述 ベたタンカー船型の場合 $C$ の值は $\beta$ によって顕著に変化 しているが， $C_{p}$ は $\beta$ に対して一定であることから，こ の性質は $C_{s}$ すなわち船体による整流効果の特性に起因 していることになる。この結果は, 平均的な流れとして みた場合, 船体の斜航角が小さいときはこれよりも相当 大きい角度で流れがプロペラに入ることを示しており， 斜航角が小さいほど針路安定性に対して相対的に舵效き がよくなることを意味している゙)。

このよらな方法で得られた $C_{S}$ と流れの直接計測の結 果との関連をみるために, 船体を斜航させたときの伴流
計測の結果との比較を行なった。Fig. 16 に横断面に現 われる流れの模様を示す。ここに $x$ 軸は船体綎中心線上 にとる。 $x$ 方向の計測位置は $c / 2$ 間隔 ( $c$ : 舵弦長) で 舵の $1 / 4,3 / 4$ 弦長点を間に含さ 4 箇所で, この最前方 の位置を原点とし，これがほぼプロペラ位置に対応して いる。深さ方向 $(z)$ は舵の上下端, 中央の位置として いる。いま $y=0$ の面に打ける流向の平均值（ただし流 れの変動が大きいなどの理由で $x=0, z / d=0.360$ の計 測点を除外している）を考えることにし，これとさきの $C_{S}$ との比較を行なったのが Fig. 17 であるが，両者は略 々同程度の值になっている。ここではプロペラ位置が対 象となっているが局部的な変動の影響を緩和するために これより後方に括ける值を含めたので, この流向はプロ ペラ位置よりも多少後方域における值になっている。な
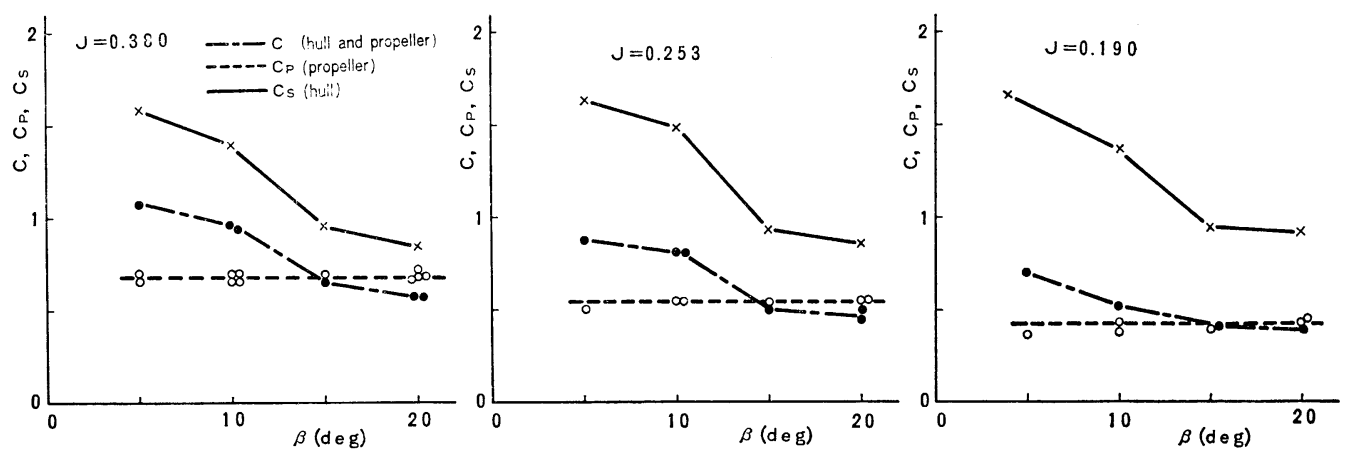

Fig. 15 Value $C_{s}$ determined from values $C$ and $C_{p}$
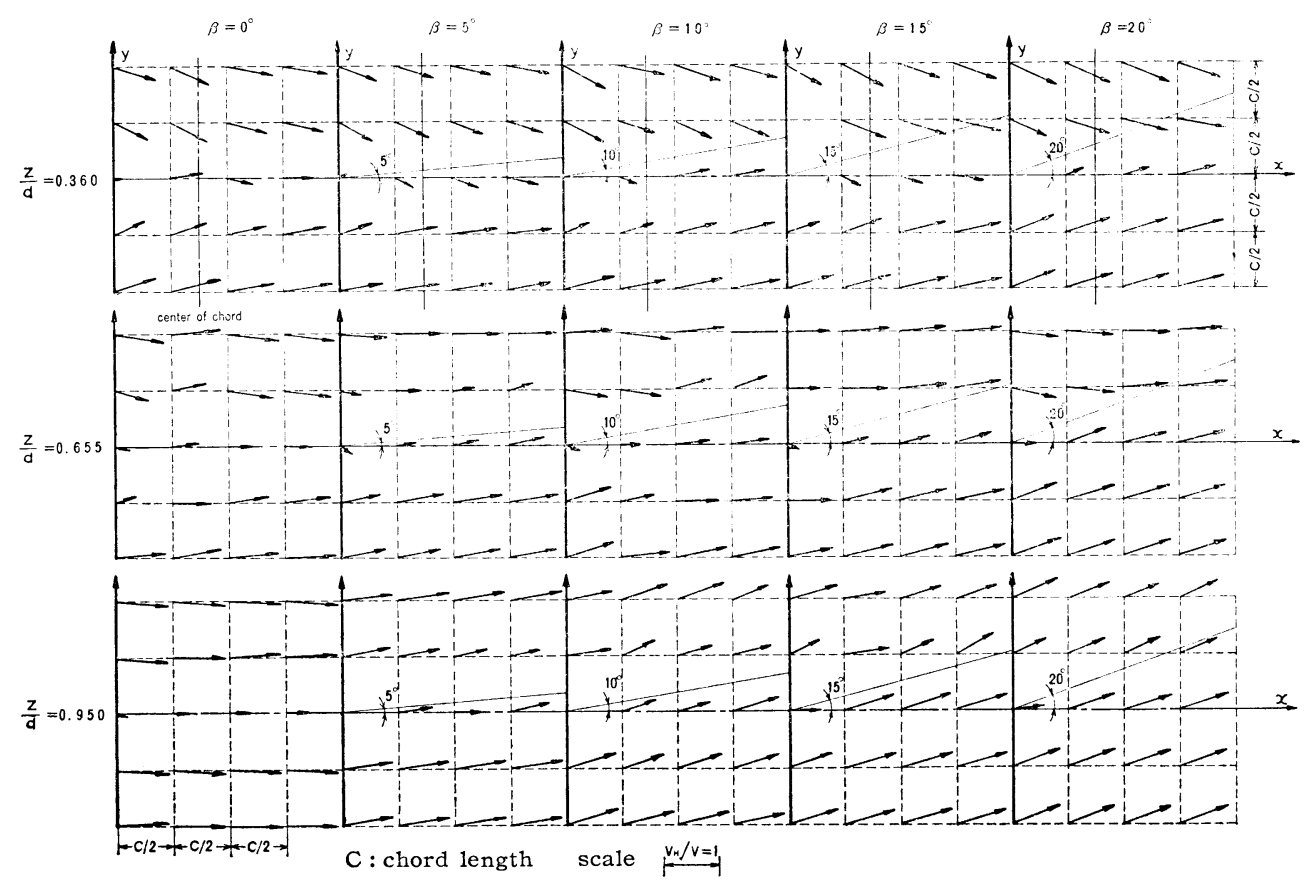

Fig. 16 Wake measurement of yawed ship's hull 


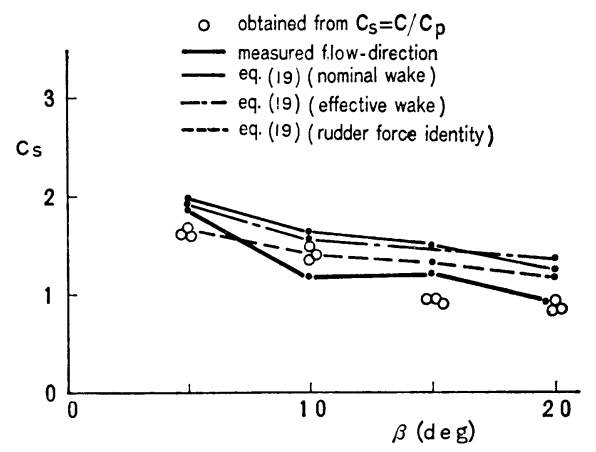

Fig. 17 Comparison of values $C_{s}$ obtained from some procedures

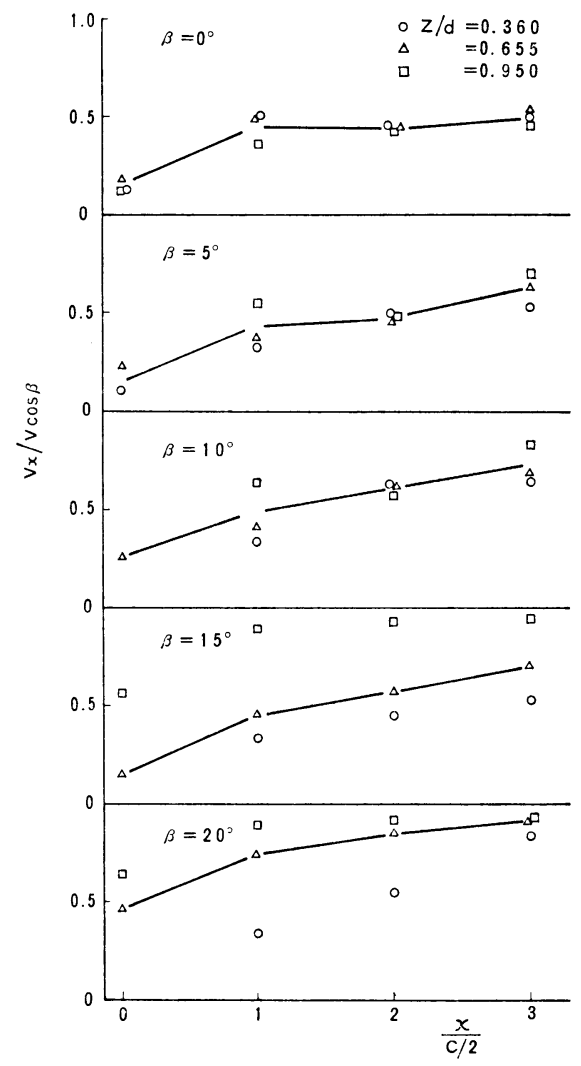

Fig. 18 Variation of wake velocity with $x$ direction

お，今後プロペラ面における流向に関する詳しい実験が 望まれる。

伴流速さの $x$ 方向の変化を示したのが Fig. 18 である。 プロペラ面を対象としたいわゆる公称伴流係数そのもの とは多少意味は異なるがさきとほ涪同じ範因における平 均值として伴流係数を定め, これの $\beta$ に対する変化を示 したのが Fig. 19 である。同図には有効伴流係数, 舵特 性から求めた值も記入している。

プロペラ整流係数を求めたときと同様に， 2 方向の流

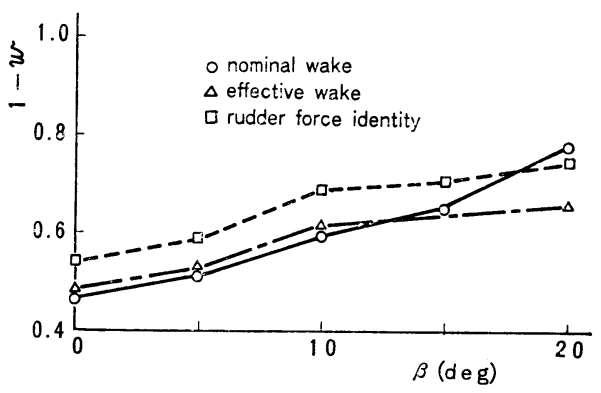

Fig. 19 Effect of drift angle on wake fraction

れに分ける方法により船体整流係数に相当する值

$$
C_{s}=\frac{\Theta_{s}}{\beta}, \quad \Theta_{s}=\frac{v}{V_{p}}
$$

を求めてみる。ここに $V_{p}$ はプロペラ位置における伴流 速度あるいはこれの $x$ 方向の成分とする。Fig. 17 に $V_{p}$ として Fig. 19 の 3 種の伴流係数を用いて得られた $C_{S}$ の值を示し, さきの $C_{s}$ および流向の值接計測の結果と 比較した。この $C_{s}$ は後 2 者よりも概して幾分大きい值 を示しているが， $\beta$ に対する変化の様子を比較的よく表 わしている。この結果から， $C_{s}$ が $\beta$ の増加とともに小 さくなる特性を伴流係数 $w$ の同様の結果と関連させて考 えることができ，このことからもある程度説明できるも のと思われる。（19）式の近似もあるので両方法による $C_{s}$ の差を直ちに船体の down-wash に関連させて考兄 ることはできないが，今後詳しい実験やさらに多くの例 によってこのあたりの事情を明確にしたいと考光てい る。

\section{7 結言}

実用的な観点からプロペラの整流効果およびこれに関 連したいくつかの問題について考察を行ない，おおよそ 次のような結果を得た。

（1）斜航するプロペラ背後の流向を直圧力が作用し ない舵の向きおよび vaneを用いる力法より定め，この 結果を整流係数の形で表わした。前者の方法による值は 舵弦長の半分の幅をもつ羽根を舵の後半部に配置したと きの值とほぼ一致し, いわゆる $3 / 4$ 弦長点の定理に相当 する結果が得られた。後者のような簡単な方法によって も羽根の大ささや配置場所を適切に選ぶことにより前者 と汇とんど同程度の值が得られる。

（2）プロペラ整流係数は斜航角に無関係に一定とな ることがこのような実験からも確認された。

（3）プロペラ整流係数に対して Hornの算定式 ${ }^{14)} は$ 実測值よりも小さい值を与える。この式に修正係数 ((12) 式の $k$ ) を考えることにすると $k=0.7$ 程度の值を必要 とする。また，プロペラ整流係数をプロペラの横流れお よび後流の合成速度の方向として算出した結果は実測值 
と良好な一致を示す。

（4）プロペラ荷重度はプロペラの整流効果に大きい 影響を及ぼす。ここに述べたタンカー船型では, 模型船 $(2.25 \mathrm{~m})$ および実船 $(300 \mathrm{~m})$ の状態に打けるプロぺ ラ整流係数の比は約 0.6 となる。舵効果の縮率影響に対 しては従来舵への流入速さのみに着目されることが多か ったが，より合理的な取扱いをするためには流入角への 影響も考慮する必要があると考えられる。

（5）推力一致法に対応するものとして，プロペラの 整流效果を介してこれへの流入角を求める考方方を示し た。この方法によって求めた船体の整流効果が船体伴流 の流向の実測結果と略々同程度となる例を示した。

（6）ここに述べたタンカー船型では船体整流係数は 斜航角の増加とともに小さくなるが，この特性は伴流 率 1-wが斜航角の増加に伴って大きくなるといらこと からある程度は説明できる。

本報告を終えるに当り，ご指導を賜わりました東京大 学元良誠三教授に心より謝意を表します。

またご援助るいただいた IHI 技術研究所の神中龍雄参 与, 田崎 亮部長, 梶田悦司部長に感謝の意を表すると ともに，実験にご協力いただいた運動性能水槽ならびに 船型試験水槽の関係各位に厚くお礼申し上げます。

\section{参考文 献}

1）藤井 斉, 津田達雄 : 自航模型による舵特性の研 究 (2)，造船協会諭文集，第 110 号（昭 36.12).

2）藤井 斉, 津田達雄 : 自航模型による舵特性の研 究 (3), 造船協会論文集, 第 111 号 (昭 37.6).

3）湯室彰規：斜航する船体の舵位置における流向に 関する実験的研究, 石川島播磨技報, 第 14 巻, 第 4 号（昭 49.7）.

4) 湯室彰規 : A Model Experiment on IncomingFlow Direction to the Rudder of a Ship Sailing Obliquely, 14 th I.T.T.C. (1975).

5) 湯室彰規 : An Experimental study on Inflow Direction and Inflow Velocity to the Rudder of a Ship in Manoeuvring Motion, Report for
Conference on Ship Manoeuvrability and Handling, Bulgaria (1978).

6) 岡田正次郎：舵性能に及汪す推進器後流の影響に ついて，造船協会論文集，第 104 号（昭 34.1）.

7) 岡田正次郎：推進器後流中に置かれた舵の性能に 関する実験結果について，造船協会諭文集，第 104 号 (昭 34.1).

8）湯室彰規：操綐性指数の縮率影響の一推定法, 日 本造船学会論文集, 第, 137 号 (昭 50.6).

9）たとえば，谷一郎：低速翼理論の二,三の間題， 航空工学講座(第 5 回), 空気力学に関する講座, 日本航空学会（昭 31.5).

10）藤本武助: 流体力学, 養賢堂（昭 42）, p.145～ 147.

11）小川陽弘，辻 豊治，森 政彦：斜航するプロペ ラに㗢く横力に関する研究，第 16 回船舶技術研 究所研究発表会講演概要 (昭 45.10).

12）中西正治，上田耕平，山崎隆介：プロペラと舵と の干涉について，西部造船会々報，第 36 号（昭 43.7).

13）上田耕平，山崎隆介：プロペラと舵との干涉につ いて(続)，西部造船会々報，第 38 号（昭 44.7).

14) F. Horn : Quarkräfte am Propeller bei Schräganströmung, speziell bei Manövriervorgängen, Schiffstechnik Heft 20. Band 4 (1957).

15) F. Gutsche : Untersuchung von Schiffsschrauben in schräger Anströmung, Schiffbauforschung 3 (1964).

16) J.E. Dickmann : Schiffskörpersog, Wellenwiderstand eines Propellers und Wechselwirkung mit Schiffswellen, Ing. Arch. (1938).

17) E. Langecker : Über den Einflu $\beta$ des Propellers auf Querkraft und Giermoment von Schiffen, Schiffbauforschung 16 (1977).

18）高木又男, 田口堅士, 細田龍介, 萬野良次: 船後 の舵特性の縮率影響について, 関西造船協会誌, 第 155 号 (昭 49.12).

19）小川陽弘, 小山健夫, 貴島勝郎: 操縱運動の数学 モデルについて, 日本造船学会誌, 第 575 号（昭 $52.5)$.

20）神中龍雄, 深瀬 彊, 湯室彰規, 山崎禎昭 : 高速 船型の旋回に関する二, 三の間題，造船協会論文 集, 第 111 号 (昭 37.6). 